Document downloaded from:

http://hdl.handle.net/10251/102402

This paper must be cited as:

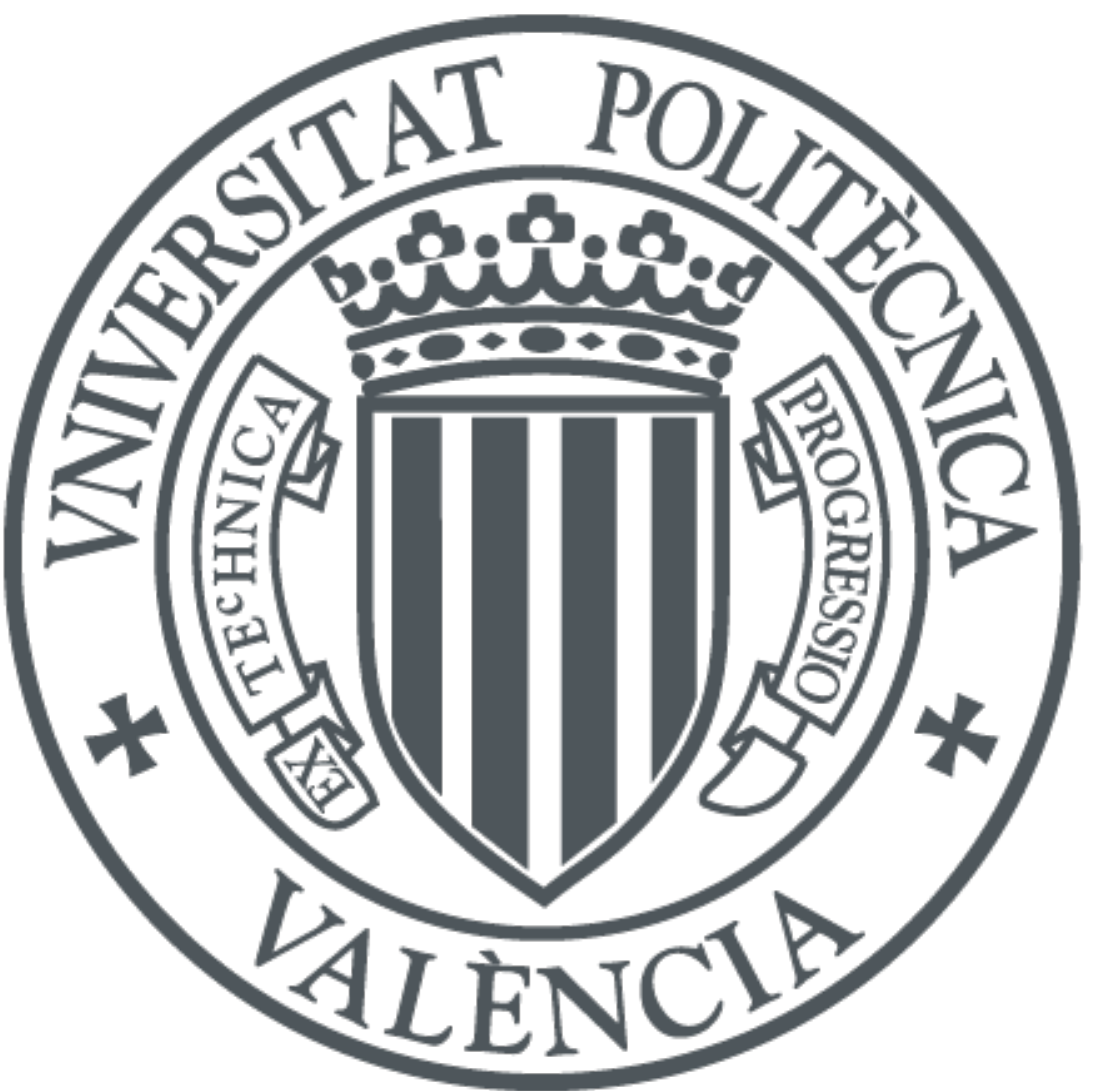

The final publication is available at

http://dx.doi.org/10.1007/978-1-4939-7165-7_1

Copyright Springer Link

Additional Information 


\title{
Plant ARGONAUTEs: Features, Functions and Unknowns
}

\begin{abstract}
Alberto Carbonell
Instituto de Biología Molecular y Celular de Plantas (Consejo Superior de

Investigaciones Científicas-Universidad Politécnica de Valencia), Valencia, 46022,

Spain
\end{abstract}

Corresponding author:

Alberto Carbonell (acarbonell@ibmcp.upv.es)

Instituto de Biología Molecular y Celular de Plantas (Consejo Superior de

Investigaciones Científicas-Universidad Politécnica de Valencia), Valencia, 46022,

Spain.

Running head: Plant ARGONAUTE proteins 


\begin{abstract}
ARGONAUTEs (AGOs) are the effector proteins in eukaryotic small RNA(sRNA)based gene silencing pathways controlling gene expression and transposon activity. In plants, AGOs regulate key biological processes such as development, response to stress, genome structure and integrity, and pathogen defense. Canonical functions of plant AGO-sRNA complexes include the endonucleolytic cleavage or translational inhibition of target RNAs, and the methylation of target DNAs. Here, I provide a brief update on the major features, molecular functions and biological roles of plant AGOs. A special focus is given to the more recent discoveries related to emerging molecular or biological functions of plant AGOs, as well as to the major unknowns in the plant AGO field.
\end{abstract}

Key words: ARGONAUTE, small RNA, RNA silencing, microRNA, Arabidopsis 


\section{Introduction}

In eukaryotes, ARGONAUTEs (AGOs) are the effector proteins functioning in small RNA (sRNA)-guided gene silencing pathways regulating gene expression and transposon activity [1]. AGO-sRNA complexes target and silence complementary DNA or RNA through posttranscriptional gene silencing (PTGS) or transcriptional gene silencing (TGS), respectively. Silencing of target transcripts occurs through either direct endonucleolytic cleavage (slicing) or through other cleavageindependent mechanisms such as target destabilization or translational repression [2].

AGOs have an ancient origin, as they are present in bacteria, archae and eukaryotes [3]. In plants, the AGO family includes a variable number of members depending on the plant species [4], with flowering plants encoding more AGOs. For example, Arabidopsis thaliana (Arabidopsis) and rice have 10 and 19 AGO members $[5,6]$ respectively, while the algae Chlamydomonas reinhardtii and the moss Physcomitrella patens have three and six [7-9] respectively. The expansion of the plant AGO family suggests a functional diversification of AGO proteins most likely during the specialization and evolution of endogenous sRNA-based RNA silencing pathways $[10,11]$. Phylogenetically, flowering plant AGOs can be grouped in three major clades: AGO1/5/10, AGO2/3/7 and AGO4/6/8/9. In addition, grasses present an expanded AGO1/5/10 clade including AGO18 [10].

Crystallographic studies on eukaryotic AGOs have determined that AGOs present four functional domains: a variable N-domain, and conserved PAZ, MID and PIWI domains [12]. The MID and PAZ domains bind the 5' monophosphorylated nucleotide and the 3' nucleotide of the sRNA, respectively. The PIWI domain is the ribonucleolytic domain, with four metal-coordinating residues required for slicer activity $[13,14]$. Plant AGOs associate with sRNA based on the identity of the 5', 
nucleotide of the sRNA and/or other sequence and structural features of the sRNA duplex and the AGO PIWI domain [15-19]. Plant AGO-sRNA complexes can function through different modes to silence complementary DNA or RNA and exert their biological role.

I present next an updated overview on the known and emerging molecular and biological roles of plant AGOs. I also highlight the main unknowns in the plant AGO field.

\section{Modes of Action of Plant AGOs}

The main modes of action of plant AGOs are summarized in Figure 1 and described next.

\subsection{Endonucleolytic Cleavage}

The PIWI domain of AGOs uses intrinsic RNAse H-like activity to cleave target RNA [20], and contains a metal-coordinating Asp-Glu-Asp-His/Asp catalytic tetrad [14,21]. Slicing activity has been experimentally confirmed for Arabidopsis AGO1 [22,23], AGO2 [24], AGO4 [25], AGO7 [15] and AGO10 [18,26].

Since the initial observation that plant microRNAs (miRNAs) targeted and cleaved highly sequence complementary target RNAs [27], it was assumed that slicing was the predominant mode of action in miRNA-mediated PTGS in plants [28]. Indeed, the high degree of complementarity is a requirement for effective target slicing by plant AGOs [29]. However, later examples describing slicing-independent translational repression of certain miRNA targets (see below) have questioned this assumption. Still, growing evidence suggest that target RNA regulation by slicing is widespread in plants. First, sequencing of Arabidopsis mRNA degradome has revealed that most 
miRNA targets undergo slicing [30,31]. Second, the slicing activity of Arabidopsis AGO1 (the primary miRNA-associating AGO), AGO2 and AGO7 is critical for plant development, antiviral activity and juvenile to adult phase transition, respectively [24], while AGO4 and AGO10 exert their primary functions in a slicer-independent mode $[18,25]$. And third, recent transcriptome profiling of agol null and slicerdeficient Arabidopsis mutants confirmed that AGO1 slicer activity is necessary for the repression of the majority of miRNA targets [32].

Slicing activity of plant AGOs is also required for triggering the amplification of phased secondary small interfering RNAs (phasiRNAs) from certain target transcripts. For instance, trans-acting small interfering RNAs (tasiRNA), a class of secondary small interfering RNAs (siRNAs) that forms through a refined mechanism, derive from four families of $T A S$ transcripts that are initially cleaved by AGO1-miR173, AGO1-miR828 or AGO7-miR390 complexes to produce TAS1/TAS2, TAS4 and TAS3-derived tasiRNAs respectively [15,24,33-37]. Interestingly, a recent comparative analysis of tasiRNA generation in wild-type, agol null and agol slicer deficient Arabidopsis showed that slicing by AGO1 is required for the definition of the phase but not for the generation of TAS-derived tasiRNAs [38].

The subcellular location of miRNA-mediated target cleavage has been largely unknown. However, the observation that a reduced level of isoprenoids, which are essential for membrane sterols, blocks miRNA-mediated cleavage of several target transcripts suggests that membrane association of AGO1 is important for target cleavage [39]. In a recent work, Arabidopsis miRNAs were shown to associate with membrane-bound polysomes as opposed to polysomes in general, and this association was required for miRNA-triggered phasiRNA production [40]. Because slicing is 
required for phasiRNA production, it appears that, at least, part of the AGO-mediated target cleavage activity occurs in membrane-bound polysomes.

\subsection{Translational Repression}

Translational repression by miRNAs is common in animals where miRNA-target RNA interactions require limited sequence complementarity [41]. In plants, several evidences suggest that AGO-miRNA complexes can also translationally repress their targets RNAs with almost perfect complementarity [39,42-48]. Several Arabidopsis mutants impaired in miRNA-mediated gene repression at protein but not at mRNA levels have been described $[39,43,49]$ In particular, AGO1-miRNA-mediated translation repression in Arabidopsis occurs in the endoplasmic reticulum and requires the integral membrane protein ALTERED MERISTEM PROGRAM 1 to exclude target mRNAs from membrane-bound polysomes [43]. AGO10, another member of the AGO1 clade, also appears to translationally repress several Arabidopsis miRNA target genes, including AGO1 [50]. Very recently, it has been shown that AGO7miR390 binding to a non-cleavable miR390 target site included in TAS3a non-coding transcripts cause ribosome stacking and subsequent inhibition of translation elongation [51]. However, the global contribution to plant miRNA-mediated translation repression of direct blocking of ribosome movement through the binding of AGO-miRNA complexes appears to be limited [51].

\subsection{Target mRNA Decay?}

Target mRNA decay is a common outcome of AGO recruitment in animals, where the complementarity between an amiRNA and its target mRNA is generally limited to the 5' region of the miRNA and slicing is not common [52]. AGO-miRNA complexes 
destabilize target mRNAs in a process requiring both deadenylation and decapping $[53,54]$. Recruitment of the two major deadenylases CCR4-NOT and PARN requires the adaptor protein GW182/TNRC6 that binds to hydrophobic pockets in AGOs $[55,56]$. Because no homolog of GW182/TNRC6 is present in plant genomes, it is unlikely that such mechanism exists in plants. Three recent studies support this statement: i) transcriptome analyses performed on either stable or conditional slicerdeficient AGO1 mutants did not show any substantial differences in gene expression between the two classes [32], ii) efficient translational repression by either wild-type or slicer-deficient AGO1 in lysates of tobacco protoplasts is not accompanied by any kind of reporter-mRNA degradation other than slicing [42], and iii) no deadenylation has been reported in sRNA-mediated translational repression in Chlamydomonas reinhardtii [57]. However, the possibility that a subset of plant miRNA targets could be regulated by AGO-mediated mRNA decay cannot be completely ruled out.

\subsection{RNA-Dependent DNA Methylation}

DNA methylation regulates gene expression, blocks transposon movement and consequently maintains genome integrity. In plants, canonical DNA methylation is primarily mediated by AGO4-siRNA complexes functioning in RNA-dependent DNA methylation (RdDM) pathways [58]. These pathways are initiated by the synthesis of double-stranded RNA (dsRNA) by the concerted action of RNA POLYMERASE IV (Pol IV) and RNA-DEPENDENT RNA POLYMERASE 2 (RDR2) [59-63]. DsRNA processing in the nucleus by DICER-LIKE 3 (DCL3) leads to the production of 24-nt siRNAs [59] that are exported to the cytoplasm where they are incorporated into AGO4. AGO4-siRNA complexes localize to the nucleus where they are recruited to target loci via base-pairing with nascent Pol V transcripts and/or 
through their interaction with the glycine-tryptophane/thryptophane-glycine (GW/WG) AGO hook motifs present in in both Pol V [64-67] and its associated factor SUPPRESSOR OF TY INSERTION 5 (SPT5) [68,69]. Finally, AGO4-siRNA complexes recruit DOMAIN REARRANGED METHYLTRANSFERASE 2 (DRM2) protein that methylates target DNA [70,71].Very recently, AGO4 interaction with DNA has been observed at RdDM targets. It appears that Pol V-dependent transcripts or their transcription are needed to lock Pol V into a stable DNA-bound configuration that allows AGO4 recruitment via Pol V and SPT5 AGO hook motifs [72].

AGO6 is also associated with RdDM in Arabidopsis, and thought initially to have partially redundant functions with AGO4 [73]. Later studies assigned more specific features and functions for AGO6, such as its preferential association for a unique set of heterochromatic sRNAs [74], or its dominant expression in shoot and root apical meristems and not in mature leaves [75]. More recently, it has been proposed that AGO6 may indeed work sequentially with AGO4 in the methylation of most target loci [76]. In addition, AGO6 also associates with RDR6-dependent 21-22 nt sRNAs to direct the methylation of transcriptionally active transposons in Arabidopsis [77].

Unexpectedly, a combination of genetic, biochemical and bioinformatic genomewide analyses has recently showed that Arabidopsis AGO3, thought to function in PTGS as the other members of the AGO2/AGO7 clade, binds 24 nt sRNAs and can partially complement AGO4 function. The authors speculate with a role of AGO3 in RdDM in Arabidopsis [78], possibly under salinity stress when its expression is highly induced.

\subsection{Emerging AGO Functions}


Besides the well-characterized roles of plant AGOs in sRNA-mediated PTGS and TGS, new molecular functions have been described in the last years. First, Arabidopsis AGO10 and rice AGO18 sequester miR165/166 and miR168 from AGO1 to regulate shoot apical meristem (SAM) development [18] and antiviral defense [79], respectively. Rice AGO18 additionally sequesters miR528 from AGO1 upon viral infection to inhibit L-ascorbate oxidase (AO) mRNA cleavage by AGO1-miR528 complexes, thereby increasing AO-mediated accumulation of reactive oxygene species and enhancing antiviral defense [80]. Second, Arabidopsis AGO2 and AGO9 participate in the repair of double-strand break sites [81,82]. Third, AGO4 participates in an alternative siRNA biogenesis pathway by binding precursor transcripts that are subsequently subjected to 3 ' -5 ' exonucleolytic trimming for maturation and sidRNA (siRNA independent of DCLs) production [83]. AGO4sidRNA complexes target Pol V transcripts to mediate DRM2-dependent DNA methylation. And fourth, a novel role for Arabidopsis AGO1 in the cotranscriptional regulation of MIRNA gene expression under salt stress conditions has been recently reported [84]. It seems that miRNA-loaded AGO1 interacts with chromatin at MIR161 and MIR173 loci, causing the disassembly of the transcriptional complex and the release of short and unpolyadenylated transcripts [84].

\section{Biological Roles of Plant AGO Proteins}

Plant AGOs have functionally diversified during evolution due to the expansion of the AGO family because of numerous duplications and losses $[10,85,86]$. The main biological roles of plant AGOs are listed in Table 1 and described next [see [4] for a recent review]. 


\subsection{Plant AGOs and Development}

The importance of AGOs in plant development became obvious after the characterization of the first Arabidopsis agol mutants. These mutants -named "Argonaute" because of the resemblance of their leaf defects with the tentacles of a small squid of the Argonauta genus- presented important pleiotropic developmental defects such as dwarfing and sterility [87]. Later, developmental screens in Arabidopsis identified a series of hypomorphic agol alleles with reduced developmental defects. The characterization of such mutants highlighted AGO1 role in leaf polarity and lateral organ development [88-90]. The organ polarity defects exhibited by agol mutants suggested that AGO1 plays a role in the miRNA pathway, as these defects were similar to those of phabulosa $(p h b)$ and phavoluta (phv) miRNA gain-of-function mutants [91]. Agol mutants have also been characterized in rice, and show obvious pleiotropic developmental defects such as severe dwarfism, tortuous shoots, narrow and rolled leaves and low seed-setting rates [92].

Other Arabidopsis ago mutants such as ago 7 or agol0 present limited developmental defects, and others like ago2, ago3, ago4, ago5 ago6 and ago 9 have no obvious growth-related phenotypes [93]. AGO7 was identified in a screen for mutants displaying accelerated juvenile to adult phase change [94]. AGO7 associates exclusively with miR390 to target $T A S 3$ transcripts and initiate $T A S 3$-based tasiRNA biogenesis leading to the targeting of several AUXIN RESPONSE FACTOR genes involved in the regulation of developmental timing and lateral organ development in Arabidopsis [15,35,95-98]. The observation that AGO7 also participates in TAS3dependent tasiRNA biogenesis in moss [97] and in monocot species such as rice [99] and maize [100] indicates that AGO7 function in tasiRNA biogenesis is deeply conserved in plants. 
Arabidopsis AGO10 mutants (previously known as phn from "pinhead" and zll from "zwille") exhibit abnormal SAM development [101,102]. Despite that early analyses of Arabidopsis agolago10 double mutants revealed functional redundancies between the two AGOs in some aspects of development [101], later observations have assigned specific roles for AGO10. Contrary to AGO1 which is expressed ubiquitously, AGO10 is predominantly expressed in the provasculature, adaxial leaf primordia and the meristem $[101,102]$. AGO10 expression pattern is consistent with its roles in the maintenance of SAM development and leaf development in Arabidopsis [101,102] and rice [103]. More recent observations indicate that AGO10 sequesters miR165/miR166 from AGO1 to regulate SAM development [18], and associates with miR172 to favour floral determinacy [26].

\subsection{Plant AGOs and Pathogen Defense}

Plant AGOs play a key role in antiviral defense [for a recent review see [104]]. In antiviral silencing, highly structured or dsRNAs of viral origin are processed by plant DCLs into 21-24 nt virus-derived siRNAs (vsiRNAs). VsiRNAs associate with specific AGOs to target and repress cognate viral RNA through endonucleolytic cleavage or translational repression, or cognate viral DNA through hypermethylation or by regulating host gene expression to enhance antiviral defense [105]. Plant AGOs with roles in antiviral silencing include Arabidopsis AGO1, AGO2, AGO4, AGO5, AGO7 and AGO10, N. benthamiana AGO1 and AGO2, and rice AGO1 and AGO18. Plant AGOs can also bind sRNAs derived from viroids to attenuate viroid accumulation in vivo [106]. Interestingly, a recent report suggests that Arabidopsis AGO4 has direct antiviral activity against Plantago asiatica mosaic virus independent of its RdDM function [107]. 
In addition to their well-known role in antiviral defense, several Arabidopsis AGOs have antibacterial activity. In particular, AGO2 binds miR393b* to translationally repress the Golgi-localized $M E M B 12$ gene, resulting in the exocytosis of the pathogenesis-related protein PR1 with high antibacterial activity [108]. AGO4 is required for Arabidopsis resistance to Pseudomonas syringae, in a mode independent of other components of the RdDM pathway [109].

\subsection{Plant AGO Functions In Meiosis And Gametogenesis}

Plant AGOs have a key role during sexual reproduction, with specific AGOs being preferentially expressed in reproductive tissues and enriched in germline cells [110]. For instance, Arabidopsis AGO5 is expressed in the somatic cells around megaspore mother cells and in the megaspores, and ago5 mutants are impaired in megagametogenesis initiation [111]. In rice, mutations in MEIOSIS ARRESTED AT LEPTOTENE 1 (MEL1) - one of the five AGO5 homologs in rice- induces precocious meiotic arrest and male sterility, with abnormal tapetums and aberrant pollen mother cells [112]. In maize, AGO9 is expressed in ovule somatic cells surrounding female meiocytes and contributes to non-CG DNA methylation in heterochromatin, and chromosome segregation is arrested during meiosis in ago 9 mutants [113]. Both Arabidopsis and maize AGO9 act in somatic cells to regulate cell fate specification in a non-cell autonomous manner. However, Arabidopsis AGO9 represses germ cell fate in somatic cells [114] while maize AGO9 inhibits somatic cell fate in germ cells [113].

\section{Major Unknowns in the Plant AGO field}

\subsection{AGO Protein Interactors}


In principle, plant AGOs likely need co-factors to exert their functions. However, in contrast to the situation observed in other organisms, a limited number of proteins interacting with plant AGOs has been described to date. Known plant AGO interactors are i) CYCLOPHILIN 40 (CYP40), HEAT SHOCK PROTEIN 90 (HSP90) and TRANSPORTIN 1 (TRN1) which interact with AGO1 and facilitate miRNA loading [115-118], and ii) the PolV NRPE subunit [66], the transcription elongation factor SPT5 [68,69], and the the putative oxidoreductase WGRP1 [119] which interact with AGO4 via their GW/WG AGO hook motifs. Systematic genomewide scans for AGO protein interactors through more refined co-immunoprecipitation coupled with mass spectrometry analyses should identify a larger number of AGO partners, especially in response to abiotic or biotic stresses.

\subsection{AGO Target RNAs}

A fundamental requisite to understand AGO function is the identification of the whole spectrum of cellular target RNAs regulated by plant AGOs. Contrary to animal miRNAs, the majority of plant miRNAs regulate highly sequence complementary mRNAs [120]. This strict complementary feature of functionally relevant miRNAtarget interactions made early bioinformatics studies highly successful in predicting miRNA targets in plants [28]. Molecular validation of numerous plant miRNA targets has relied on the amplification by 5' Rapid Amplification of cDNA Ends (RACE) of 3' cleavage products from cell extracts [121]. Because the isolation of loss-offunction miRNA mutants is difficult due mainly to the genetic redundancy in most miRNA families, the biological significance of individual miRNA-target interactions has been explored by other genetic approaches. These include the overexpression of miRNAs, miRNA-resistance targets or target mimicries [122]. The first genome- 
wide assessment of the repertoire of miRNA target RNAs regulated by cleavage corresponds to degradome sequencing analyses [30]. It appears that many conserved canonical targets have consistently strong degradome signatures, suggesting that this approach may be more likely to detect functionally relevant targets. Unfortunately, weak signatures are also recovered from several conserved canonical targets, and new potential targets do not follow the canonical parameters of base pairing. Therefore, the functional significance of degradome signatures is still not always clear [122]. All these approaches are useful to confirm or discover miRNA targets but do not reveal which specific AGO member mediates their regulation.

Genome-wide analysis of AGO-bound target RNAs have been reported in animals by applying a step of in vivo crosslinking (generally using ultraviolet light) in intact cells of tissues before immunoprecipitating the AGO of interest and analysing by high-throughput sequencing the co-immunoprecipated AGO-bound RNAs [123]. Such AGO crosslinking immunoprecipitation followed by sequencing (CLIP-Seq) approaches have not been reported in plants. This could be due because, in contrast with animals where the majority of miRNA targets are not sliced, AGO-sRNA-target RNA interactions are ephemeral for the majority of plant target RNAs that might be immediately sliced upon AGO-miRNA recognition. Indeed, recent AGO RNA immunoprecipitation followed by high-throughput sequencing (RIP-Seq) analysis of AGO1-bound RNAs in Arabidopsis revealed that target RNAs are more efficiently co-immunoprecipitated with slicer-deficient AGO1 forms [24]. This suggests that AGO1 ternary complexes including miRNAs and target RNAs are more stable when AGO1 is catalytically inactive. By comparing the pool of target RNAs recovered from immunoprecipitates containing catalytically active or inactive AGO1 forms it is possible to identify the repertoire of AGO1 target RNAs regulated by slicing and 
those regulated in a slicing-independent mode. Moreover, the application of this methodology to the different Arabidopsis AGOs could reveal the specific pool of target RNAs regulated by each specific AGO in different stress conditions or cell types. Understanding AGO-sRNA-target RNA dynamics is crucial to better understand sRNA-mediated gene silencing in plants.

\subsection{AGO Transcriptional Regulators}

While some plant AGOs such as Arabidopsis AGO1 and AGO4 are ubiquitously expressed, others have a more restricted expression. This is the case of Arabidopsis AGO9 and AGO10, which are expressed in female gamete and their accessory cells [114], or in provasculature, adaxial leaf primordia and the meristem [101,102], respectively. Moreover, several AGOs are induced upon abiotic or biotic stress. For instance, rice AGO18 accumulation is induced upon viral infection [79], while AGO2 and AGO3 accumulation is induced by gamma-irradiation and bacterial infection [108], and salt stress [78], respectively. The differential spatiotemporal expression of the distinct AGO members as well as the induction of certain AGOs upon stress suggests that AGO transcription may be regulated. However, transcriptional regulators of plant AGOs are largely unknown. Only recently, it was shown that Arabidopsis AGO10 expression is activated by at least one homeodomain-leucine zipper (HD-ZIP) transcription factor [124], and inhibited by the LBD12-1 transcription factor that directly binds to AGO10 promoter [125].

\section{Conclusions and Future Challenges}

Intensive research over the past two decades has elucidated the main functions of plant AGOs. However, future research should identify new functions for plant AGOs, 
as occurred for AGOs from other organisms. Emerging functions of non-plant AGOs include nonsense-mediated mRNA decay regulation in humans [126], alternative splicing in humans $[127,128]$ and Drosophila [129], sRNA-independent association with full-length introns (called "agotrons") to control gene expression in humans and probably in other mammals [130], nucleosome occupancy at human transcription start sites [131] and quality control of human proteins entering the secretory pathway [132]. Remarkably, DNA-guided genome editing has been recently reported in human cells using Natronobacterium gregoryi AGO [133], although failure to replicate these results by other groups [134] has questioned the general applicability of this approach. Several outstanding questions remain to be answered in the plant AGO field. At the molecular level, more structural work is needed to better understand the formation of AGO ternary complexes. In particular, how AGOs scan and find target transcripts? Or, how ternary complexes dissociate? Indeed, to date no crystal structure for a complete plant AGO has been solved. Also, besides AGO4 binding to sidRNA precursors, can other AGOs regulate target RNAs in a sRNA guide-independent mode? Regarding sRNA-mediated translational repression of target RNAs, what is the degree of miRNA-target RNA complementarity necessary to support the translational inhibition activity of plant miRNAs? Can AGOs other than AGO1 or AGO10 be programmed to function in a translational repression mode? And for those target RNAs regulated by slicing and translational repression $[39,46,135]$, what mechanism(s) underlie the choice between these two modes of action? At a cellular level, how AGO ternary complexes are programmed in different cell-types and tissues? Cell-type specific profiling of AGO-small RNA-target RNA dynamics in different cell-types and tissues should shed light on the role of the different AGO modules in the large regulatory networks established during development and stress 
response. Because of the broad interest of these fundamental questions, I anticipate that at least some of them will be answered soon.

\section{Ackowledgements}

This work was supported by an Individual Fellowship from the European Union's Horizon 2020 research and innovation programme under the Marie Sklodowska Curie grant agreement No. 655841 to A.C. 


\section{References}

1. Meister G (2013) Argonaute proteins: functional insights and emerging roles. Nat Rev Genet 14 (7):447-459. doi:10.1038/nrg3462

2. Huntzinger E, Izaurralde E (2011) Gene silencing by microRNAs: contributions of translational repression and mRNA decay. Nat Rev Genet 12 (2):99-110.

doi:10.1038/nrg2936

3. Cerutti H, Casas-Mollano JA (2006) On the origin and functions of RNA-mediated silencing: from protists to man. Curr Genet 50 (2):81-99. doi:10.1007/s00294-0060078-x

4. Fang X, Qi Y (2016) RNAi in Plants: An Argonaute-Centered View. Plant Cell 28 (2):272-285. doi:10.1105/tpc. 15.00920

5. Kapoor M, Arora R, Lama T, Nijhawan A, Khurana JP, Tyagi AK, Kapoor S (2008) Genome-wide identification, organization and phylogenetic analysis of Dicerlike, Argonaute and RNA-dependent RNA polymerase gene families and their expression analysis during reproductive development and stress in rice. BMC Genomics 9:451. doi:10.1186/1471-2164-9-451

6. Morel JB, Godon C, Mourrain P, Beclin C, Boutet S, Feuerbach F, Proux F, Vaucheret H (2002) Fertile hypomorphic ARGONAUTE (ago1) mutants impaired in post-transcriptional gene silencing and virus resistance. Plant Cell 14 (3):629-639. doi:10.1105/tpc.010358

7. Yamasaki T, Kim EJ, Cerutti H, Ohama T (2016) Argonaute3 is a key player in miRNA-mediated target cleavage and translational repression in Chlamydomonas. Plant J 85 (2):258-268. doi:10.1111/tpj.13107

8. Schroda M (2006) RNA silencing in Chlamydomonas: mechanisms and tools. Curr Genet 49 (2):69-84. doi:10.1007/s00294-005-0042-1 
9. Arif MA, Frank W, Khraiwesh B (2013) Role of RNA interference (RNAi) in the moss Physcomitrella patens. Int J Mol Sci 14 (1):1516-1540.

doi:10.3390/ijms14011516

10. Zhang H, Xia R, Meyers BC, Walbot V (2015) Evolution, functions, and mysteries of plant ARGONAUTE proteins. Curr Opin Plant Biol 27:84-90. doi:10.1016/j.pbi.2015.06.011

11. Chapman EJ, Carrington JC (2007) Specialization and evolution of endogenous small RNA pathways. Nat Rev Genet 8 (11):884-896. doi:10.1038/nrg2179 12. Tolia NH, Joshua-Tor L (2007) Slicer and the argonautes. Nat Chem Biol 3 (1):36-43. doi:10.1038/nchembio848

13. Song JJ, Smith SK, Hannon GJ, Joshua-Tor L (2004) Crystal structure of Argonaute and its implications for RISC slicer activity. Science 305 (5689):14341437. doi:10.1126/science. 1102514

14. Nakanishi K, Weinberg DE, Bartel DP, Patel DJ (2012) Structure of yeast Argonaute with guide RNA. Nature 486 (7403):368-374. doi:10.1038/nature11211 15. Montgomery TA, Howell MD, Cuperus JT, Li D, Hansen JE, Alexander AL, Chapman EJ, Fahlgren N, Allen E, Carrington JC (2008) Specificity of ARGONAUTE7-miR390 interaction and dual functionality in TAS3 trans-acting siRNA formation. Cell 133 (1):128-141. doi:10.1016/j.cell.2008.02.033 16. Mi S, Cai T, Hu Y, Chen Y, Hodges E, Ni F, Wu L, Li S, Zhou H, Long C, Chen S, Hannon GJ, Qi Y (2008) Sorting of small RNAs into Arabidopsis Argonaute complexes is directed by the $5^{\prime}$ terminal nucleotide. Cell 133 (1):116-127. doi:10.1016/j.cell.2008.02.034 
17. Takeda A, Iwasaki S, Watanabe T, Utsumi M, Watanabe Y (2008) The mechanism selecting the guide strand from small RNA duplexes is different among argonaute proteins. Plant Cell Physiol 49 (4):493-500. doi:10.1093/pcp/pcn043 18. Zhu H, Hu F, Wang R, Zhou X, Sze SH, Liou LW, Barefoot A, Dickman M, Zhang X (2011) Arabidopsis Argonaute10 specifically sequesters miR166/165 to regulate shoot apical meristem development. Cell 145 (2):242-256. doi:10.1016/j.cell.2011.03.024

19. Zhang X, Niu D, Carbonell A, Wang A, Lee A, Tun V, Wang Z, Carrington JC, Chang CE, Jin H (2014) ARGONAUTE PIWI domain and microRNA duplex structure regulate small RNA sorting in Arabidopsis. Nat Commun 5:5468. doi:10.1038/ncomms6468

20. Liu J, Carmell MA, Rivas FV, Marsden CG, Thomson JM, Song JJ, Hammond SM, Joshua-Tor L, Hannon GJ (2004) Argonaute2 is the catalytic engine of mammalian RNAi. Science 305 (5689):1437-1441. doi:10.1126/science.1102513 21. Sheng G, Zhao H, Wang J, Rao Y, Tian W, Swarts DC, van der Oost J, Patel DJ, Wang Y (2014) Structure-based cleavage mechanism of Thermus thermophilus Argonaute DNA guide strand-mediated DNA target cleavage. Proc Natl Acad Sci U S A 111 (2):652-657. doi:10.1073/pnas.1321032111

22. Baumberger N, Baulcombe DC (2005) Arabidopsis ARGONAUTE1 is an RNA slicer that selectively recruits microRNAs and short interfering RNAs. Proc Natl Acad Sci U S A 102 (33):11928-11933. doi:10.1073/pnas.0505461102

23. Qi Y, Denli AM, Hannon GJ (2005) Biochemical specialization within Arabidopsis RNA silencing pathways. Mol Cell 19 (3):421-428. doi:10.1016/j.molcel.2005.06.014 
24. Carbonell A, Fahlgren N, Garcia-Ruiz H, Gilbert KB, Montgomery TA, Nguyen T, Cuperus JT, Carrington JC (2012) Functional analysis of three Arabidopsis ARGONAUTES using slicer-defective mutants. Plant Cell 24 (9):3613-3629. doi:10.1105/tpc.112.099945

25. Qi Y, He X, Wang XJ, Kohany O, Jurka J, Hannon GJ (2006) Distinct catalytic and non-catalytic roles of ARGONAUTE4 in RNA-directed DNA methylation. Nature 443 (7114):1008-1012. doi:10.1038/nature05198

26. Ji L, Liu X, Yan J, Wang W, Yumul RE, Kim YJ, Dinh TT, Liu J, Cui X, Zheng B, Agarwal M, Liu C, Cao X, Tang G, Chen X (2011) ARGONAUTE10 and ARGONAUTE1 regulate the termination of floral stem cells through two microRNAs in Arabidopsis. PLoS Genet 7 (3):e1001358. doi:10.1371/journal.pgen.1001358 27. Llave C, Xie Z, Kasschau KD, Carrington JC (2002) Cleavage of Scarecrow-like mRNA targets directed by a class of Arabidopsis miRNA. Science 297 (5589):20532056. doi:10.1126/science. 1076311

28. Rhoades MW, Reinhart BJ, Lim LP, Burge CB, Bartel B, Bartel DP (2002) Prediction of plant microRNA targets. Cell 110 (4):513-520. doi:10.1016/S00928674(02)00863-2

29. Mallory AC, Reinhart BJ, Jones-Rhoades MW, Tang G, Zamore PD, Barton MK, Bartel DP (2004) MicroRNA control of PHABULOSA in leaf development: importance of pairing to the microRNA 5' region. EMBO J 23 (16):3356-3364. doi:10.1038/sj.emboj. 7600340

30. German MA, Pillay M, Jeong DH, Hetawal A, Luo S, Janardhanan P, Kannan V, Rymarquis LA, Nobuta K, German R, De Paoli E, Lu C, Schroth G, Meyers BC, Green PJ (2008) Global identification of microRNA-target RNA pairs by parallel analysis of RNA ends. Nat Biotechnol 26 (8):941-946. doi:10.1038/nbt1417 
31. Addo-Quaye C, Eshoo TW, Bartel DP, Axtell MJ (2008) Endogenous siRNA and miRNA targets identified by sequencing of the Arabidopsis degradome. Curr Biol 18 (10):758-762. doi:10.1016/j.cub.2008.04.042

32. Arribas-Hernandez L, Kielpinski LJ, Brodersen P (2016) mRNA decay of most Arabidopsis miRNA targets requires slicer activity of AGO1. Plant Physiol 171

(4):2620-2632. doi:10.1104/pp.16.00231

33. Cuperus JT, Carbonell A, Fahlgren N, Garcia-Ruiz H, Burke RT, Takeda A, Sullivan CM, Gilbert SD, Montgomery TA, Carrington JC (2010) Unique functionality of 22-nt miRNAs in triggering RDR6-dependent siRNA biogenesis from target transcripts in Arabidopsis. Nat Struct Mol Biol 17 (8):997-1003.

doi:10.1038/nsmb.1866

34. Montgomery TA, Yoo SJ, Fahlgren N, Gilbert SD, Howell MD, Sullivan CM, Alexander A, Nguyen G, Allen E, Ahn JH, Carrington JC (2008) AGO1-miR173 complex initiates phased siRNA formation in plants. Proc Natl Acad Sci U S A 105 (51):20055-20062. doi:10.1073/pnas.0810241105

35. Allen E, Xie Z, Gustafson AM, Carrington JC (2005) microRNA-directed phasing during trans-acting siRNA biogenesis in plants. Cell 121 (2):207-221. doi:10.1016/j.cell.2005.04.004

36. Yoshikawa M, Peragine A, Park MY, Poethig RS (2005) A pathway for the biogenesis of trans-acting siRNAs in Arabidopsis. Genes Dev 19 (18):2164-2175. doi:10.1101/gad.1352605

37. Rajagopalan R, Vaucheret H, Trejo J, Bartel DP (2006) A diverse and evolutionarily fluid set of microRNAs in Arabidopsis thaliana. Genes Dev 20 (24):3407-3425. doi:10.1101/gad.1476406 
38. Arribas-Hernandez L, Marchais A, Poulsen C, Haase B, Hauptmann J, Benes V, Meister G, Brodersen P (2016) The slicer activity of ARGONAUTE1 Is required specifically for the phasing, not production, of trans-acting short interfering RNAs in Arabidopsis. Plant Cell 28 (7):1563-1580. doi:10.1105/tpc.16.00121

39. Brodersen P, Sakvarelidze-Achard L, Bruun-Rasmussen M, Dunoyer P, Yamamoto YY, Sieburth L, Voinnet O (2008) Widespread translational inhibition by plant miRNAs and siRNAs. Science 320 (5880):1185-1190.

doi:10.1126/science. 1159151

40. Li S, Le B, Ma X, Li S, You C, Yu Y, Zhang B, Liu L, Gao L, Shi T, Zhao Y, Mo B, Cao X, Chen X (2016) Biogenesis of phased siRNAs on membrane-bound polysomes in Arabidopsis. Elife 5. doi:10.7554/eLife.22750

41. Zeng Y, Yi R, Cullen BR (2003) MicroRNAs and small interfering RNAs can inhibit mRNA expression by similar mechanisms. Proc Natl Acad Sci U S A 100 (17):9779-9784. doi:10.1073/pnas.1630797100

42. Iwakawa HO, Tomari Y (2013) Molecular insights into microRNA-mediated translational repression in plants. Mol Cell 52 (4):591-601. doi:10.1016/j.molcel.2013.10.033

43. Li S, Liu L, Zhuang X, Yu Y, Liu X, Cui X, Ji L, Pan Z, Cao X, Mo B, Zhang F, Raikhel N, Jiang L, Chen X (2013) MicroRNAs inhibit the translation of target mRNAs on the endoplasmic reticulum in Arabidopsis. Cell 153 (3):562-574. doi:10.1016/j.cell.2013.04.005 44. Li JF, Chung HS, Niu Y, Bush J, McCormack M, Sheen J (2013) Comprehensive protein-based artificial microRNA screens for effective gene silencing in plants. Plant Cell 25 (5):1507-1522. doi:10.1105/tpc.113.112235 
45. Liu MJ, Wu SH, Wu JF, Lin WD, Wu YC, Tsai TY, Tsai HL, Wu SH (2013)

Translational landscape of photomorphogenic Arabidopsis. Plant Cell 25 (10):36993710. doi:10.1105/tpc.113.114769

46. Aukerman MJ, Sakai H (2003) Regulation of flowering time and floral organ identity by a microRNA and its APETALA2-like target genes. Plant Cell 15

(11):2730-2741. doi:10.1105/tpc.016238

47. Chen X (2004) A microRNA as a translational repressor of APETALA2 in Arabidopsis flower development. Science 303 (5666):2022-2025.

doi:10.1126/science. 1088060

48. Gandikota M, Birkenbihl RP, Hohmann S, Cardon GH, Saedler H, Huijser P (2007) The miRNA156/157 recognition element in the 3' UTR of the Arabidopsis SBP box gene SPL3 prevents early flowering by translational inhibition in seedlings. Plant J 49 (4):683-693. doi:10.1111/j.1365-313X.2006.02983.x

49. Yang L, Wu G, Poethig RS (2012) Mutations in the GW-repeat protein SUO reveal a developmental function for microRNA-mediated translational repression in Arabidopsis. Proc Natl Acad Sci U S A 109 (1):315-320.

doi:10.1073/pnas.1114673109

50. Mallory AC, Hinze A, Tucker MR, Bouche N, Gasciolli V, Elmayan T, Lauressergues D, Jauvion V, Vaucheret H, Laux T (2009) Redundant and specific roles of the ARGONAUTE proteins AGO1 and ZLL in development and small RNAdirected gene silencing. PLoS Genet 5 (9):e1000646.

doi:10.1371/journal.pgen.1000646

51. Hou CY, Lee WC, Chou HC, Chen AP, Chou SJ, Chen HM (2016) Global analysis of truncated RNA ends reveals new insights into ribosome stalling in plants. Plant Cell 28 (10):2398-2416. doi:10.1105/tpc.16.00295 
52. Rogers K, Chen X (2013) Biogenesis, turnover, and mode of action of plant microRNAs. Plant Cell 25 (7):2383-2399. doi:10.1105/tpc.113.113159

53. Behm-Ansmant I, Rehwinkel J, Doerks T, Stark A, Bork P, Izaurralde E (2006) mRNA degradation by miRNAs and GW182 requires both CCR4:NOT deadenylase and DCP1:DCP2 decapping complexes. Genes Dev 20 (14):1885-1898.

doi:10.1101/gad.1424106

54. Wu L, Fan J, Belasco JG (2006) MicroRNAs direct rapid deadenylation of mRNA. Proc Natl Acad Sci U S A 103 (11):4034-4039.

doi:10.1073/pnas.0510928103

55. Schirle NT, MacRae IJ (2012) The crystal structure of human Argonaute2. Science 336 (6084):1037-1040. doi:10.1126/science.1221551

56. Pfaff J, Hennig J, Herzog F, Aebersold R, Sattler M, Niessing D, Meister G (2013) Structural features of Argonaute-GW182 protein interactions. Proc Natl Acad Sci U S A 110 (40):E3770-3779. doi:10.1073/pnas.1308510110

57. Ma X, Kim EJ, Kook I, Ma F, Voshall A, Moriyama E, Cerutti H (2013) Small interfering RNA-mediated translation repression alters ribosome sensitivity to inhibition by cycloheximide in Chlamydomonas reinhardtii. Plant Cell 25 (3):985998. doi:10.1105/tpc.113.109256

58. Law JA, Jacobsen SE (2010) Establishing, maintaining and modifying DNA methylation patterns in plants and animals. Nat Rev Genet 11 (3):204-220. doi:10.1038/nrg2719

59. Xie Z, Johansen LK, Gustafson AM, Kasschau KD, Lellis AD, Zilberman D, Jacobsen SE, Carrington JC (2004) Genetic and functional diversification of small RNA pathways in plants. PLoS Biol 2 (5):E104. doi:10.1371/journal.pbio.0020104 
60. Herr AJ, Jensen MB, Dalmay T, Baulcombe DC (2005) RNA polymerase IV directs silencing of endogenous DNA. Science 308 (5718):118-120.

doi:10.1126/science. 1106910

61. Kanno T, Huettel B, Mette MF, Aufsatz W, Jaligot E, Daxinger L, Kreil DP, Matzke M, Matzke AJ (2005) Atypical RNA polymerase subunits required for RNAdirected DNA methylation. Nat Genet 37 (7):761-765. doi:10.1038/ng1580

62. Onodera Y, Haag JR, Ream T, Costa Nunes P, Pontes O, Pikaard CS (2005) Plant nuclear RNA polymerase IV mediates siRNA and DNA methylation-dependent heterochromatin formation. Cell 120 (5):613-622. doi:10.1016/j.cell.2005.02.007 63. Haag JR, Ream TS, Marasco M, Nicora CD, Norbeck AD, Pasa-Tolic L, Pikaard CS (2012) In vitro transcription activities of Pol IV, Pol V, and RDR2 reveal coupling of Pol IV and RDR2 for dsRNA synthesis in plant RNA silencing. Mol Cell 48 (5):811-818. doi:10.1016/j.molcel.2012.09.027

64. Pontes O, Li CF, Costa Nunes P, Haag J, Ream T, Vitins A, Jacobsen SE, Pikaard CS (2006) The Arabidopsis chromatin-modifying nuclear siRNA pathway involves a nucleolar RNA processing center. Cell 126 (1):79-92. doi:10.1016/j.cell.2006.05.031 65. Li CF, Pontes O, El-Shami M, Henderson IR, Bernatavichute YV, Chan SW, Lagrange T, Pikaard CS, Jacobsen SE (2006) An ARGONAUTE4-containing nuclear processing center colocalized with Cajal bodies in Arabidopsis thaliana. Cell 126 (1):93-106. doi:10.1016/j.cell.2006.05.032

66. El-Shami M, Pontier D, Lahmy S, Braun L, Picart C, Vega D, Hakimi MA, Jacobsen SE, Cooke R, Lagrange T (2007) Reiterated WG/GW motifs form functionally and evolutionarily conserved ARGONAUTE-binding platforms in RNAi-related components. Genes Dev 21 (20):2539-2544. doi:10.1101/gad.451207 
67. Li CF, Henderson IR, Song L, Fedoroff N, Lagrange T, Jacobsen SE (2008)

Dynamic regulation of ARGONAUTE4 within multiple nuclear bodies in Arabidopsis thaliana. PLoS Genet 4 (2):e27. doi:10.1371/journal.pgen.0040027

68. Bies-Etheve N, Pontier D, Lahmy S, Picart C, Vega D, Cooke R, Lagrange T (2009) RNA-directed DNA methylation requires an AGO4-interacting member of the SPT5 elongation factor family. EMBO Rep 10 (6):649-654.

doi:10.1038/embor.2009.31

69. He XJ, Hsu YF, Zhu S, Wierzbicki AT, Pontes O, Pikaard CS, Liu HL, Wang CS, Jin H, Zhu JK (2009) An effector of RNA-directed DNA methylation in Arabidopsis is an ARGONAUTE 4- and RNA-binding protein. Cell 137 (3):498-508.

doi:10.1016/j.cell.2009.04.028

70. Zhong X, Du J, Hale CJ, Gallego-Bartolome J, Feng S, Vashisht AA, Chory J, Wohlschlegel JA, Patel DJ, Jacobsen SE (2014) Molecular mechanism of action of plant DRM de novo DNA methyltransferases. Cell 157 (5):1050-1060.

doi:10.1016/j.cell.2014.03.056

71. Cao X, Jacobsen SE (2002) Locus-specific control of asymmetric and CpNpG methylation by the DRM and CMT3 methyltransferase genes. Proc Natl Acad Sci U S A 99 Suppl 4:16491-16498. doi:10.1073/pnas.162371599

72. Lahmy S, Pontier D, Bies-Etheve N, Laudie M, Feng S, Jobet E, Hale CJ, Cooke R, Hakimi MA, Angelov D, Jacobsen SE, Lagrange T (2016) Evidence for ARGONAUTE4-DNA interactions in RNA-directed DNA methylation in plants. Genes Dev 30 (23):2565-2570. doi:10.1101/gad.289553.116

73. Zheng X, Zhu J, Kapoor A, Zhu JK (2007) Role of Arabidopsis AGO6 in siRNA accumulation, DNA methylation and transcriptional gene silencing. EMBO J 26 (6):1691-1701. doi:10.1038/sj.emboj.7601603 
74. Havecker ER, Wallbridge LM, Hardcastle TJ, Bush MS, Kelly KA, Dunn RM, Schwach F, Doonan JH, Baulcombe DC (2010) The Arabidopsis RNA-directed DNA methylation Argonautes functionally diverge based on their expression and interaction with target loci. Plant Cell 22 (2):321-334. doi:10.1105/tpc.109.072199

75. Eun C, Lorkovic ZJ, Naumann U, Long Q, Havecker ER, Simon SA, Meyers BC, Matzke AJ, Matzke M (2011) AGO6 functions in RNA-mediated transcriptional gene silencing in shoot and root meristems in Arabidopsis thaliana. PLoS One 6 (10):e25730. doi:10.1371/journal.pone.0025730

76. Duan CG, Zhang H, Tang K, Zhu X, Qian W, Hou YJ, Wang B, Lang Z, Zhao Y, Wang X, Wang P, Zhou J, Liang G, Liu N, Wang C, Zhu JK (2015) Specific but interdependent functions for Arabidopsis AGO4 and AGO6 in RNA-directed DNA methylation. EMBO J 34 (5):581-592. doi:10.15252/embj.201489453

77. McCue AD, Panda K, Nuthikattu S, Choudury SG, Thomas EN, Slotkin RK (2015) ARGONAUTE 6 bridges transposable element mRNA-derived siRNAs to the establishment of DNA methylation. EMBO J 34 (1):20-35.

doi:10.15252/embj.201489499

78. Zhang Z, Liu X, Guo X, Wang XJ, Zhang X (2016) Arabidopsis AGO3 predominantly recruits $24-\mathrm{nt}$ small RNAs to regulate epigenetic silencing. Nat Plants 2 (5):16049. doi:10.1038/nplants.2016.49

79. Wu J, Yang Z, Wang Y, Zheng L, Ye R, Ji Y, Zhao S, Ji S, Liu R, Xu L, Zheng H, Zhou Y, Zhang X, Cao X, Xie L, Wu Z, Qi Y, Li Y (2015) Viral-inducible Argonaute18 confers broad-spectrum virus resistance in rice by sequestering a host microRNA. Elife 4. doi:10.7554/eLife.05733

80. Wu J, Yang R, Yang Z, Yao S, Zhao S, Wang Y, Li P, Song X, Jin L, Zhou T, Lan Y, Xie L, Zhou X, Chu C, Qi Y, Cao X, Li Y (2017) ROS accumulation and 
antiviral defence control by microRNA528 in rice. Nat Plants 3:16203. doi:10.1038/nplants.2016.203

81. Wei W, Ba Z, Gao M, Wu Y, Ma Y, Amiard S, White CI, Rendtlew Danielsen JM, Yang YG, Qi Y (2012) A role for small RNAs in DNA double-strand break repair. Cell 149 (1):101-112. doi:10.1016/j.cell.2012.03.002

82. Oliver C, Santos JL, Pradillo M (2014) On the role of some ARGONAUTE proteins in meiosis and DNA repair in Arabidopsis thaliana. Front Plant Sci 5:177. doi:10.3389/fpls.2014.00177

83. Ye R, Chen Z, Lian B, Rowley MJ, Xia N, Chai J, Li Y, He XJ, Wierzbicki AT, Qi Y (2016) A Dicer-independent route for biogenesis of siRNAs that direct DNA methylation in Arabidopsis. Mol Cell 61 (2):222-235. doi:10.1016/j.molcel.2015.11.015

84. Dolata J, Bajczyk M, Bielewicz D, Niedojadlo K, Niedojadlo J, Pietrykowska H, Walczak W, Szweykowska-Kulinska Z, Jarmolowski A (2016) Salt Stress Reveals a New Role for ARGONAUTE1 in miRNA Biogenesis at the Transcriptional and Posttranscriptional Levels. Plant Physiol 172 (1):297-312. doi:10.1104/pp.16.00830 85. Singh RK, Gase K, Baldwin IT, Pandey SP (2015) Molecular evolution and diversification of the Argonaute family of proteins in plants. BMC Plant Biol 15 (1):23. doi:10.1186/s12870-014-0364-6

86. Singh RK, Pandey SP (2015) Evolution of structural and functional diversification among plant Argonautes. Plant Signal Behav 10 (10):e1069455. doi:10.1080/15592324.2015.1069455

87. Bohmert K, Camus I, Bellini C, Bouchez D, Caboche M, Benning C (1998) AGO1 defines a novel locus of Arabidopsis controlling leaf development. EMBO J 17 (1):170-180. doi:10.1093/emboj/17.1.170 
88. Kidner CA, Martienssen RA (2004) Spatially restricted microRNA directs leaf polarity through ARGONAUTE1. Nature 428 (6978):81-84. doi:10.1038/nature02366 89. Sorin C, Bussell JD, Camus I, Ljung K, Kowalczyk M, Geiss G, McKhann H, Garcion C, Vaucheret H, Sandberg G, Bellini C (2005) Auxin and light control of adventitious rooting in Arabidopsis require ARGONAUTE1. Plant Cell 17 (5):13431359. doi:10.1105/tpc. 105.031625

90. Yang L, Huang W, Wang H, Cai R, Xu Y, Huang H (2006) Characterizations of a hypomorphic argonaute1 mutant reveal novel AGO1 functions in Arabidopsis lateral organ development. Plant Mol Biol 61 (1-2):63-78. doi:10.1007/s11103-005-5992-7 91. Kidner CA, Martienssen RA (2005) The developmental role of microRNA in plants. Curr Opin Plant Biol 8 (1):38-44. doi:10.1016/j.pbi.2004.11.008 92. Wu L, Zhang Q, Zhou H, Ni F, Wu X, Qi Y (2009) Rice microRNA effector complexes and targets. Plant Cell 21 (11):3421-3435. doi:10.1105/tpc.109.070938 93. Vaucheret H (2008) Plant ARGONAUTES. Trends Plant Sci 13 (7):350-358. doi:10.1016/j.tplants.2008.04.007

94. Hunter C, Sun H, Poethig RS (2003) The Arabidopsis heterochronic gene ZIPPY is an ARGONAUTE family member. Curr Biol 13 (19):1734-1739 95. Adenot X, Elmayan T, Lauressergues D, Boutet S, Bouche N, Gasciolli V, Vaucheret H (2006) DRB4-dependent TAS3 trans-acting siRNAs control leaf morphology through AGO7. Curr Biol 16 (9):927-932. doi:10.1016/j.cub.2006.03.035 96. Fahlgren N, Montgomery TA, Howell MD, Allen E, Dvorak SK, Alexander AL, Carrington JC (2006) Regulation of AUXIN RESPONSE FACTOR3 by TAS3 tasiRNA affects developmental timing and patterning in Arabidopsis. Curr Biol 16 (9):939-944. doi:10.1016/j.cub.2006.03.065 
97. Axtell MJ, Jan C, Rajagopalan R, Bartel DP (2006) A two-hit trigger for siRNA biogenesis in plants. Cell 127 (3):565-577. doi:10.1016/j.cell.2006.09.032 98. Hunter C, Willmann MR, Wu G, Yoshikawa M, de la Luz Gutierrez-Nava M, Poethig SR (2006) Trans-acting siRNA-mediated repression of ETTIN and ARF4 regulates heteroblasty in Arabidopsis. Development 133 (15):2973-2981. doi:10.1242/dev.02491

99. Nagasaki H, Itoh J, Hayashi K, Hibara K, Satoh-Nagasawa N, Nosaka M, Mukouhata M, Ashikari M, Kitano H, Matsuoka M, Nagato Y, Sato Y (2007) The small interfering RNA production pathway is required for shoot meristem initiation in rice. Proc Natl Acad Sci U S A 104 (37):14867-14871. doi:10.1073/pnas.0704339104 100. Douglas RN, Wiley D, Sarkar A, Springer N, Timmermans MC, Scanlon MJ (2010) Ragged seedling2 encodes an ARGONAUTE7-like protein required for mediolateral expansion, but not dorsiventrality, of maize leaves. Plant Cell 22 (5):1441-1451. doi:10.1105/tpc.109.071613

101. Lynn K, Fernandez A, Aida M, Sedbrook J, Tasaka M, Masson P, Barton MK (1999) The PINHEAD/ZWILLE gene acts pleiotropically in Arabidopsis development and has overlapping functions with the ARGONAUTE1 gene. Development 126 (3):469-481

102. Moussian B, Schoof H, Haecker A, Jurgens G, Laux T (1998) Role of the ZWILLE gene in the regulation of central shoot meristem cell fate during Arabidopsis embryogenesis. EMBO J 17 (6):1799-1809. doi:10.1093/emboj/17.6.1799 103. Nishimura A, Ito M, Kamiya N, Sato Y, Matsuoka M (2002) OsPNH1 regulates leaf development and maintenance of the shoot apical meristem in rice. Plant J 30 (2):189-201 
104. Carbonell A, Carrington JC (2015) Antiviral roles of plant ARGONAUTES. Curr Opin Plant Biol 27:111-117. doi:10.1016/j.pbi.2015.06.013

105. Szittya G, Burgyan J (2013) RNA interference-mediated intrinsic antiviral immunity in plants. Curr Top Microbiol Immunol 371:153-181. doi:10.1007/978-3642-37765-5_6

106. Minoia S, Carbonell A, Di Serio F, Gisel A, Carrington JC, Navarro B, Flores R (2014) Specific argonautes selectively bind small RNAs derived from potato spindle tuber viroid and attenuate viroid accumulation in vivo. J Virol 88 (20):11933-11945. doi:10.1128/JVI.01404-14

107. Brosseau C, El Oirdi M, Adurogbangba A, Ma X, Moffett P (2016) Antiviral defense involves AGO4 in an Arabidopsis-Potexvirus interaction. Mol Plant Microbe Interact 29 (11):878-888. doi:10.1094/MPMI-09-16-0188-R

108. Zhang X, Zhao H, Gao S, Wang WC, Katiyar-Agarwal S, Huang HD, Raikhel N, Jin H (2011) Arabidopsis Argonaute 2 regulates innate immunity via miRNA393( *)mediated silencing of a Golgi-localized SNARE gene, MEMB12. Mol Cell 42 (3):356-366. doi:10.1016/j.molcel.2011.04.010

109. Agorio A, Vera P (2007) ARGONAUTE4 is required for resistance to Pseudomonas syringae in Arabidopsis. Plant Cell 19 (11):3778-3790. doi:10.1105/tpc.107.054494 110. Borges F, Martienssen RA (2015) The expanding world of small RNAs in plants. Nat Rev Mol Cell Biol 16 (12):727-741. doi:10.1038/nrm4085

111. Tucker MR, Okada T, Hu Y, Scholefield A, Taylor JM, Koltunow AM (2012) Somatic small RNA pathways promote the mitotic events of megagametogenesis during female reproductive development in Arabidopsis. Development 139 (8):13991404. doi:10.1242/dev.075390 
112. Nonomura K, Morohoshi A, Nakano M, Eiguchi M, Miyao A, Hirochika H, Kurata N (2007) A germ cell specific gene of the ARGONAUTE family is essential for the progression of premeiotic mitosis and meiosis during sporogenesis in rice. Plant Cell 19 (8):2583-2594. doi:10.1105/tpc.107.053199

113. Singh M, Goel S, Meeley RB, Dantec C, Parrinello H, Michaud C, Leblanc O, Grimanelli D (2011) Production of viable gametes without meiosis in maize deficient for an ARGONAUTE protein. Plant Cell 23 (2):443-458. doi:10.1105/tpc.110.079020 114. Olmedo-Monfil V, Duran-Figueroa N, Arteaga-Vazquez M, Demesa-Arevalo E, Autran D, Grimanelli D, Slotkin RK, Martienssen RA, Vielle-Calzada JP (2010) Control of female gamete formation by a small RNA pathway in Arabidopsis. Nature 464 (7288):628-632. doi:10.1038/nature08828

115. Iki T, Yoshikawa M, Nishikiori M, Jaudal MC, Matsumoto-Yokoyama E, Mitsuhara I, Meshi T, Ishikawa M (2010) In vitro assembly of plant RNA-induced silencing complexes facilitated by molecular chaperone HSP90. Mol Cell 39 (2):282291. doi:10.1016/j.molcel.2010.05.014

116. Iki T, Yoshikawa M, Meshi T, Ishikawa M (2012) Cyclophilin 40 facilitates HSP90-mediated RISC assembly in plants. EMBO J 31 (2):267-278.

doi:10.1038/emboj.2011.395

117. Smith MR, Willmann MR, Wu G, Berardini TZ, Moller B, Weijers D, Poethig RS (2009) Cyclophilin 40 is required for microRNA activity in Arabidopsis. Proc Natl Acad Sci U S A 106 (13):5424-5429. doi:10.1073/pnas.0812729106 118. Cui Y, Fang X, Qi Y (2016) TRANSPORTIN1 promotes the association of microRNA with ARGONAUTE1 in Arabidopsis. Plant Cell 28 (10):2576-2585. doi: $10.1105 /$ tpc. 16.00384 
119. Karlowski WM, Zielezinski A, Carrere J, Pontier D, Lagrange T, Cooke R (2010) Genome-wide computational identification of WG/GW Argonaute-binding proteins in Arabidopsis. Nucleic Acids Res 38 (13):4231-4245. doi:10.1093/nar/gkq162 120. Axtell MJ (2013) Classification and comparison of small RNAs from plants. Annu Rev Plant Biol 64:137-159. doi:10.1146/annurev-arplant-050312-120043 121. Jones-Rhoades MW, Bartel DP, Bartel B (2006) MicroRNAS and their regulatory roles in plants. Annu Rev Plant Biol 57:19-53. doi:10.1146/annurev.arplant.57.032905.105218 122. Li J, Reichel M, Li Y, Millar AA (2014) The functional scope of plant microRNA-mediated silencing. Trends Plant Sci 19 (12):750-756. doi:10.1016/j.tplants.2014.08.006

123. Mittal N, Zavolan M (2014) Seq and CLIP through the miRNA world. Genome Biol 15 (1):202. doi:10.1186/gb4151

124. Brandt R, Xie Y, Musielak T, Graeff M, Stierhof YD, Huang H, Liu CM, Wenkel S (2013) Control of stem cell homeostasis via interlocking microRNA and microProtein feedback loops. Mech Dev 130 (1):25-33.

doi:10.1016/j.mod.2012.06.007

125. Ma W, Wu F, Sheng P, Wang X, Zhang Z, Zhou K, Zhang H, Hu J, Lin Q, Cheng Z, Wang J, Zhu S, Zhang X, Guo X, Wang H, Wu C, Zhai H, Wan J (2017) The LBD12-1 transcription factor suppresses apical meristem size by repressing Argonaute 10 expression. Plant Physiol 173 (1):801-811. doi:10.1104/pp.16.01699 126. Choe J, Cho H, Lee HC, Kim YK (2010) microRNA/Argonaute 2 regulates nonsense-mediated messenger RNA decay. EMBO Rep 11 (5):380-386. doi:10.1038/embor.2010.44 
127. Ameyar-Zazoua M, Rachez C, Souidi M, Robin P, Fritsch L, Young R, Morozova N, Fenouil R, Descostes N, Andrau JC, Mathieu J, Hamiche A, Ait-Si-Ali S, Muchardt C, Batsche E, Harel-Bellan A (2012) Argonaute proteins couple chromatin silencing to alternative splicing. Nat Struct Mol Biol 19 (10):998-1004. doi:10.1038/nsmb.2373

128. Allo M, Agirre E, Bessonov S, Bertucci P, Gomez Acuna L, Buggiano V, Bellora N, Singh B, Petrillo E, Blaustein M, Minana B, Dujardin G, Pozzi B, Pelisch F, Bechara E, Agafonov DE, Srebrow A, Luhrmann R, Valcarcel J, Eyras E, Kornblihtt AR (2014) Argonaute-1 binds transcriptional enhancers and controls constitutive and alternative splicing in human cells. Proc Natl Acad Sci U S A 111 (44):15622-15629. doi:10.1073/pnas.1416858111

129. Taliaferro JM, Aspden JL, Bradley T, Marwha D, Blanchette M, Rio DC (2013) Two new and distinct roles for Drosophila Argonaute-2 in the nucleus: alternative pre-mRNA splicing and transcriptional repression. Genes Dev 27 (4):378-389. doi:10.1101/gad.210708.112

130. Hansen TB, Veno MT, Jensen TI, Schaefer A, Damgaard CK, Kjems J (2016) Argonaute-associated short introns are a novel class of gene regulators. Nat Commun 7:11538. doi:10.1038/ncomms 11538

131. Carissimi C, Laudadio I, Cipolletta E, Gioiosa S, Mihailovich M, Bonaldi T, Macino G, Fulci V (2015) ARGONAUTE2 cooperates with SWI/SNF complex to determine nucleosome occupancy at human Transcription Start Sites. Nucleic Acids Res 43 (3):1498-1512. doi:10.1093/nar/gku1387

132. Karamyshev AL, Patrick AE, Karamysheva ZN, Griesemer DS, Hudson H, Tjon-Kon-Sang S, Nilsson I, Otto H, Liu Q, Rospert S, von Heijne G, Johnson AE, 
Thomas PJ (2014) Inefficient SRP interaction with a nascent chain triggers a mRNA quality control pathway. Cell 156 (1-2):146-157. doi:10.1016/j.cell.2013.12.017 133. Gao F, Shen XZ, Jiang F, Wu Y, Han C (2016) DNA-guided genome editing using the Natronobacterium gregoryi Argonaute. Nat Biotechnol 34 (7):768-773. doi:10.1038/nbt.3547

134. Lee SH, Turchiano G, Ata H, Nowsheen S, Romito M, Lou Z, Ryu SM, Ekker SC, Cathomen T, Kim JS (2016) Failure to detect DNA-guided genome editing using Natronobacterium gregoryi Argonaute. Nat Biotechnol 35 (1):17-18. doi:10.1038/nbt.3753

135. Beauclair L, Yu A, Bouche N (2010) microRNA-directed cleavage and translational repression of the copper chaperone for superoxide dismutase mRNA in Arabidopsis. Plant J 62 (3):454-462. doi:10.1111/j.1365-313X.2010.04162.x 136. Garcia-Ruiz H, Carbonell A, Hoyer JS, Fahlgren N, Gilbert KB, Takeda A, Giampetruzzi A, Garcia Ruiz MT, McGinn MG, Lowery N, Martinez Baladejo MT, Carrington JC (2015) Roles and programming of Arabidopsis ARGONAUTE proteins during Turnip mosaic virus infection. PLoS Pathog 11 (3):e1004755. doi:10.1371/journal.ppat.1004755

137. Qu F, Ye X, Morris TJ (2008) Arabidopsis DRB4, AGO1, AGO7, and RDR6 participate in a DCL4-initiated antiviral RNA silencing pathway negatively regulated by DCL1. Proc Natl Acad Sci U S A 105 (38):14732-14737. doi:10.1073/pnas.0805760105 138. Wang XB, Jovel J, Udomporn P, Wang Y, Wu Q, Li WX, Gasciolli V, Vaucheret H, Ding SW (2011) The 21-nucleotide, but not 22-nucleotide, viral secondary small interfering RNAs direct potent antiviral defense by two cooperative 
argonautes in Arabidopsis thaliana. Plant Cell 23 (4):1625-1638.

doi:10.1105/tpc.110.082305

139. Dzianott A, Sztuba-Solinska J, Bujarski JJ (2012) Mutations in the antiviral RNAi defense pathway modify Brome mosaic virus RNA recombinant profiles. Mol Plant Microbe Interact 25 (1):97-106. doi:10.1094/MPMI-05-11-0137

140. Harvey JJ, Lewsey MG, Patel K, Westwood J, Heimstadt S, Carr JP, Baulcombe DC (2011) An antiviral defense role of AGO2 in plants. PLoS One 6 (1):e14639. doi:10.1371/journal.pone.0014639

141. Jaubert M, Bhattacharjee S, Mello AF, Perry KL, Moffett P (2011)

ARGONAUTE2 mediates RNA-silencing antiviral defenses against Potato virus $\mathrm{X}$ in Arabidopsis. Plant Physiol 156 (3):1556-1564. doi:10.1104/pp.111.178012

142. Ma X, Nicole MC, Meteignier LV, Hong N, Wang G, Moffett P (2015) Different roles for RNA silencing and RNA processing components in virus recovery and virusinduced gene silencing in plants. J Exp Bot 66 (3):919-932. doi:10.1093/jxb/eru447 143. Cao M, Du P, Wang X, Yu YQ, Qiu YH, Li W, Gal-On A, Zhou C, Li Y, Ding SW (2014) Virus infection triggers widespread silencing of host genes by a distinct class of endogenous siRNAs in Arabidopsis. Proc Natl Acad Sci U S A 111 (40):14613-14618. doi:10.1073/pnas.1407131111

144. Hamera S, Song X, Su L, Chen X, Fang R (2012) Cucumber mosaic virus suppressor $2 \mathrm{~b}$ binds to AGO4-related small RNAs and impairs AGO4 activities. Plant J 69 (1):104-115. doi:10.1111/j.1365-313X.2011.04774.X

145. Bhattacharjee S, Zamora A, Azhar MT, Sacco MA, Lambert LH, Moffett P (2009) Virus resistance induced by NB-LRR proteins involves Argonaute4-dependent translational control. Plant J 58 (6):940-951. doi:10.1111/j.1365-313X.2009.03832.x 
146. Raja P, Sanville BC, Buchmann RC, Bisaro DM (2008) Viral genome methylation as an epigenetic defense against geminiviruses. J Virol 82 (18):89979007. doi:10.1128/JVI.00719-08

147. Raja P, Jackel JN, Li S, Heard IM, Bisaro DM (2014) Arabidopsis doublestranded RNA binding protein DRB3 participates in methylation-mediated defense against geminiviruses. J Virol 88 (5):2611-2622. doi:10.1128/JVI.02305-13

148. Brosseau C, Moffett P (2015) Functional and genetic analysis identify a role for Arabidopsis ARGONAUTE5 in antiviral RNA silencing. Plant Cell 27 (6):17421754. doi:10.1105/tpc. 15.00264

149. Ghoshal B, Sanfacon H (2014) Temperature-dependent symptom recovery in Nicotiana benthamiana plants infected with tomato ringspot virus is associated with reduced translation of viral RNA2 and requires ARGONAUTE 1. Virology 456457:188-197. doi:10.1016/j.virol.2014.03.026

150. Scholthof HB, Alvarado VY, Vega-Arreguin JC, Ciomperlik J, Odokonyero D, Brosseau C, Jaubert M, Zamora A, Moffett P (2011) Identification of an ARGONAUTE for antiviral RNA silencing in Nicotiana benthamiana. Plant Physiol 156 (3):1548-1555. doi:10.1104/pp.111.178764

151. Fatyol K, Ludman M, Burgyan J (2016) Functional dissection of a plant Argonaute. Nucleic Acids Res 44 (3):1384-1397. doi:10.1093/nar/gkv1371 152. Odokonyero D, Mendoza MR, Alvarado VY, Zhang J, Wang X, Scholthof HB (2015) Transgenic down-regulation of ARGONAUTE2 expression in Nicotiana benthamiana interferes with several layers of antiviral defenses. Virology 486:209218. doi:10.1016/j.virol.2015.09.008 153. Vaucheret H, Vazquez F, Crete P, Bartel DP (2004) The action of ARGONAUTE1 in the miRNA pathway and its regulation by the miRNA pathway 
are crucial for plant development. Genes Dev 18 (10):1187-1197.

doi:10.1101/gad.1201404

154. Liu X, Tang S, Jia G, Schnable JC, Su H, Tang C, Zhi H, Diao X (2016) The Cterminal motif of SiAGO1b is required for the regulation of growth, development and stress responses in foxtail millet (Setaria italica (L.) P. Beauv). J Exp Bot 67 (11):3237-3249. doi:10.1093/jxb/erw135

155. Zilberman D, Cao X, Jacobsen SE (2003) ARGONAUTE4 control of locusspecific siRNA accumulation and DNA and histone methylation. Science 299 (5607):716-719. doi:10.1126/science.1079695

156. Wu L, Mao L, Qi Y (2012) Roles of dicer-like and argonaute proteins in TASderived small interfering RNA-triggered DNA methylation. Plant Physiol 160 (2):990-999. doi:10.1104/pp.112.200279

157. Nuthikattu S, McCue AD, Panda K, Fultz D, DeFraia C, Thomas EN, Slotkin RK (2013) The initiation of epigenetic silencing of active transposable elements is triggered by RDR6 and 21-22 nucleotide small interfering RNAs. Plant Physiol 162 (1):116-131. doi:10.1104/pp.113.216481

158. Wu L, Zhou H, Zhang Q, Zhang J, Ni F, Liu C, Qi Y (2010) DNA methylation mediated by a microRNA pathway. Mol Cell 38 (3):465-475.

doi:10.1016/j.molcel.2010.03.008

159. Zhai J, Zhang H, Arikit S, Huang K, Nan GL, Walbot V, Meyers BC (2015)

Spatiotemporally dynamic, cell-type-dependent premeiotic and meiotic phasiRNAs in maize anthers. Proc Natl Acad Sci U S A 112 (10):3146-3151.

doi:10.1073/pnas.1418918112 
160. Xu L, Yang L, Pi L, Liu Q, Ling Q, Wang H, Poethig RS, Huang H (2006)

Genetic interaction between the AS1-AS2 and RDR6-SGS3-AGO7 pathways for leaf morphogenesis. Plant Cell Physiol 47 (7):853-863. doi:10.1093/pcp/pcj057

161. Oliver C, Santos JL, Pradillo M (2016) Accurate chromosome segregation at first meiotic division requires $\mathrm{AGO} 4$, a protein involved in RNA-dependent DNA methylation in Arabidopsis thaliana. Genetics 204 (2):543-553. doi:10.1534/genetics.116.189217

162. Liu Q, Yao X, Pi L, Wang H, Cui X, Huang H (2009) The ARGONAUTE10 gene modulates shoot apical meristem maintenance and establishment of leaf polarity by repressing miR165/166 in Arabidopsis. Plant J 58 (1):27-40. doi:10.1111/j.1365313X.2008.03757.X

163. Zhou Y, Honda M, Zhu H, Zhang Z, Guo X, Li T, Li Z, Peng X, Nakajima K, Duan L, Zhang X (2015) Spatiotemporal sequestration of miR165/166 by Arabidopsis Argonaute10 promotes shoot apical meristem maintenance. Cell Rep 10 (11):18191827. doi:10.1016/j.celrep.2015.02.047

164. Li W, Cui X, Meng Z, Huang X, Xie Q, Wu H, Jin H, Zhang D, Liang W (2012) Transcriptional regulation of Arabidopsis MIR168a and argonaute1 homeostasis in abscisic acid and abiotic stress responses. Plant Physiol 158 (3):1279-1292. doi:10.1104/pp.111.188789 165. Earley K, Smith M, Weber R, Gregory B, Poethig R (2010) An endogenous Fbox protein regulates ARGONAUTE1 in Arabidopsis thaliana. Silence 1 (1):15. doi:10.1186/1758-907X-1-15 
Table 1 Biological roles of plant ARGONAUTEs

\begin{tabular}{|c|c|c|}
\hline Function & AGO involved $^{\mathbf{a}}$ & References \\
\hline Antibacterial immunity & $\begin{array}{l}\text { AtAGO2 } \\
\text { AtAGO4 }\end{array}$ & $\begin{array}{l}{[108]} \\
{[109]}\end{array}$ \\
\hline Antiviral defense & $\begin{array}{l}\text { AtAGO1 } \\
\text { AtAGO2 } \\
\text { AtAGO4 } \\
\text { AtAGO5 } \\
\text { AtAGO7 } \\
\text { AtAGO10 } \\
\text { NbAGO1 } \\
\text { NbAGO2 } \\
\text { OsAGO1a/b } \\
\text { OsAGO18 }\end{array}$ & $\begin{array}{l}{[6,136-139]} \\
{[17,24,136,138,140-143]} \\
{[107,142,144-147]} \\
{[136,148]} \\
{[136,137]} \\
{[136]} \\
{[149]} \\
{[150-152]} \\
{[79]} \\
{[79]}\end{array}$ \\
\hline $\begin{array}{l}\text { Cell specification } \\
\text { Gamete } \\
\text { Somatic } \\
\end{array}$ & $\begin{array}{l}\text { AtAGO9 } \\
\text { ZmAGO9 }\end{array}$ & $\begin{array}{l}{[114]} \\
{[113]}\end{array}$ \\
\hline Chromosome segregation & ZmAGO9 & {$[113]$} \\
\hline Development & $\begin{array}{l}\text { AtAGO1 } \\
\text { OsAGO1a/b/c } \\
\text { SiAGO1b }\end{array}$ & $\begin{array}{l}{[22-24,87,153]} \\
{[92]} \\
{[154]}\end{array}$ \\
\hline DNA methylation & $\begin{array}{l}\text { AtAGO3 } \\
\text { AtAGO4 } \\
\text { AtAGO6 } \\
\text { OsAGO4a } \\
\text { OsAGO4b }\end{array}$ & $\begin{array}{l}{[78]} \\
{[25,64,65,72,155,156]} \\
{[73,74,76,77,156,157]} \\
{[158]} \\
{[158]}\end{array}$ \\
\hline DNA repair & $\begin{array}{l}\text { AtAGO2 } \\
\text { AtAGO9 }\end{array}$ & $\begin{array}{l}{[81]} \\
{[82]}\end{array}$ \\
\hline Germ cell development & $\mathrm{ZmAGO18b}$ & [159] \\
\hline Leaf development & $\begin{array}{l}\text { AtAGO1 } \\
\text { AtAGO7 } \\
\text { OsAGO10 } \\
\text { ZmAGO7 }\end{array}$ & $\begin{array}{l}{[87,88]} \\
{[95,160]} \\
{[103]} \\
{[100]}\end{array}$ \\
\hline Meiosis & $\begin{array}{l}\text { AtAGO4 } \\
\text { OsAGO5c }\end{array}$ & $\begin{array}{l}{[161]} \\
{[112]}\end{array}$ \\
\hline Megagametogenesis & AtAGO5 & {$[111]$} \\
\hline Phase transition & AtAGO7 & {$[15,24,94,95]$} \\
\hline SAM development & $\begin{array}{l}\text { AtAGO10 } \\
\text { OsAGO7 }\end{array}$ & $\begin{array}{l}{[18,26,101,102,162,163]} \\
{[99]}\end{array}$ \\
\hline SAM maintenance & OsAGO10 & {$[103]$} \\
\hline $\begin{array}{l}\text { Small RNA biogenesis } \\
\text { miRNA } \\
\text { siRNA } \\
\text { tasiRNA }\end{array}$ & $\begin{array}{l}\text { AtAGO1 } \\
\text { AtAGO4 } \\
\text { AtAGO1 } \\
\text { AtAGO7 } \\
\text { OsAGO7 } \\
\text { ZmAGO7 }\end{array}$ & $\begin{array}{l}{[84]} \\
{[83]} \\
{[34]} \\
{[15]} \\
{[99]} \\
{[100]}\end{array}$ \\
\hline Stress response & $\begin{array}{l}\text { AtAGO1 } \\
\text { SiAGO1b }\end{array}$ & $\begin{array}{l}{[164,165]} \\
{[154]}\end{array}$ \\
\hline Tapetum development & $\mathrm{ZmAGO18b}$ & [159] \\
\hline
\end{tabular}




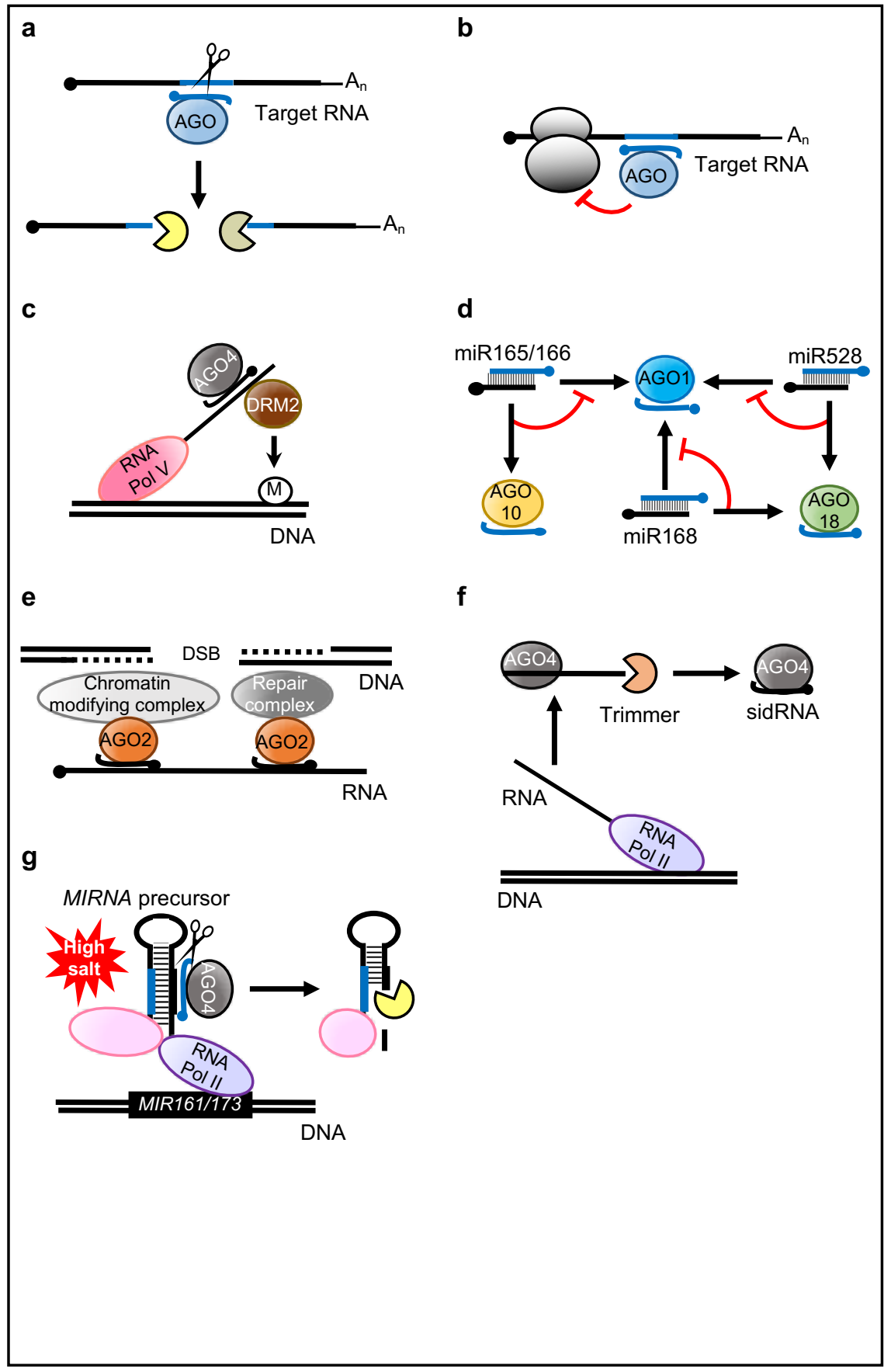

Fig.1 Modes of action of plant AGOs. (a) Endonucleolytic cleavage. Several AGOs bind sRNAs and slice highly sequence complementary target RNAs. Cleavage products are degraded by components of endogenous degradation pathways. (b) Translational repression. Plant AGOs such as Arabidopsis AGO1 and AGO10 associate with miRNAs and target highly complementary RNAs to inhibit their translation. (c) Canonical RdDM pathway. AGO4-siRNA complexes bind to nascent 
Pol V transcripts. DRM2 is recruited to mediate DNA methylation. (d) MiRNA sequestration. Arabidopsis AGO10 sequesters miR165/166 from AGO1, while rice AGO18 sequesters miR168 and miR528 from AGO1. (e) Double-stranded break repair (DSB). Arabidopsis AGO2 binds to DSB-induced siRNAs (diRNAs) to mediate DSB repair. (f) DCL-independent siRNA biogenesis. AGO4 binds to nascent Pol II RNAs which are trimmed by a 3'-5' exonuclease to produce sidRNAs. (g) Cotranscriptional regulation of MIRNA gene expression. Upon salinity stress AGO4 directs the slicing of nascent MIR161 or MIR173 precursors to cotranscriptionally regulate miRNA production. 